\title{
Haosgel: Kinship, class and urban transformations
}

\section{Christine Jourdan}

\section{(2) OpenEdition}

1 Journals

Electronic version

URL: http://journals.openedition.org/jso/7905

DOI: $10.4000 /$ jso. 7905

ISSN: $1760-7256$

\section{Publisher}

Société des océanistes

\section{Printed version}

Date of publication: 15 December 2017

Number of pages: 131-146

ISSN: 0300-953x

\section{Electronic reference}

Christine Jourdan, "Haosgel: Kinship, class and urban transformations", Journal de la Société des Océanistes [Online], 144-145 | 2017, Online since 15 December 2019, connection on 15 March 2021. URL: http://journals.openedition.org/jso/7905 ; DOI: https://doi.org/10.4000/jso.7905

This text was automatically generated on 15 March 2021.

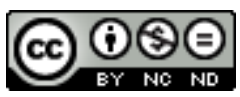

Journal de la société des océanistes est mis à disposition selon les termes de la Licence Creative Commons Attribution - Pas d'Utilisation Commerciale - Pas de Modification 4.0 International. 


\title{
Haosgel: Kinship, class and urban transformations
}

\author{
Christine Jourdan
}

1 In Honiara, many urban households, expatriate or not, employ young female domestic helpers known by the Solomon Islands Pijin term of haosgel (or haosgele ${ }^{1}$ depending on speakers' phonology). The term first appeared in Pijin, the local lingua franca, in association with colonial days: it referred to Solomon Islands women employed as maids in British or other expatriate households which often also included a cook and a gardener. ${ }^{2}$ The house girl was paid wages and was sometimes housed and fed. of course, there existed no kinship relationship with their employers. ${ }^{3}$ Women, who in general find domestic work to be a valuable activity, do not hesitate to work as house girls when they need to earn money.

2 But in contemporary urban Solomon Islands, domestic helpers are not found exclusively in expatriate households. Haosgel are found in many Melanesian middleclass urban households. In most of them, the haosgel is always related through kinship to the head couple of the household. ${ }^{4}$ She is typically a young unmarried niece or cousin who hails from the village to work as domestic help for her $\mathrm{kin}^{5}$. In these cases, the house girl is lodged and fed in the household where she works and receives some compensation for her work in the form of wages and/or household goods and clothes. The increasing social and economic pressures found in Honiara have created a demand and a need for paid employment. These are matched by an ever-increasing gap between affluent middle-class and working class people.

3 The haosgel occupies a position that is socially defined and recognized. Because the practice of having house girls exists partly in continuity with the colonial past, it could be argued that many middle class Honiarans have bought into a system of values, particularly with regard to domestic work, that is very much inherited from colonial times and that speaks to the establishment and reinforcement of social differentiation. And in some ways, that is true. But it could be argued as well that the practice is also in continuity with a tradition of exchange that permeates social relationships in Melanesia: exchange of work and services, exchange of valuables, exchange of persons 
and, principally, exchange of girls. And that argument would also be true if only in view of the never-severed social tie that links some urbanites to their rural kin. In the Solomon Islands, that link is still centrally constitutive of sociality for most urban residents (Feinberg 1995; Kwai'oloa and Burt 1997) though as Jourdan (1994); Berg (2000); Maggio (2014); McDougall (2016) have shown, that link is eroding in some families. Still it can be said that power relationships and obligations within families are carried over from the village to town and affect the movement of people between rural and urban areas as well as the exchange of prestations and services. The house girls found in urban Melanesian households are part of that link. Indeed, they epitomize this link.

4 This article explores what is it to be a young haosgel in Honiara today while focusing on social roles and family hierarchy, which, though central to the life of these young women, speak to an important aspect of the sociality of urbanization: the tensions between kinship obligations and the development of class. These young women engage a complex situation in which their urban relatives, usually wealthier than their own parents, act out kinship while playing boss. Following a well-established tradition of interpretive anthropology, I seek to understand wider social phenomena by looking at their micro manifestations in the lives of individuals.

5 The article starts with some considerations on fosterage and urbanization in Honiara and moves to an analysis of the haosgel and their situation, including a discussion of tensions that exist between kinship and employment. The paper concludes with some considerations on the transformations of family relationships in town and on the place of kinship in the development of the middle class.

\section{Kinship and Fosterage}

6 Since the work of Esther Goody (1982) on child fosterage in Benin, anthropologists around the world have paid much attention to the different forms that this practice takes and on their economic and practical rationale. As Suzanne Lallemand (1988) and Alber (2003) remark, why some societies foster their children and why others do not is certainly linked to the very entrenched societal idea about who are the best people to raise a child. ${ }^{6}$ But it is also linked to a certain conception of kinship and its production and reproduction. The circulation of children, as Leblic (2014: 452) argues with regards to adoption particularly, is yet another way for societies to produce kinship (see also Lallemand (1988) and Leblic (2004). Though this analysis holds true for the cases I am analyzing here, one cannot ignore the fact that some practices of urban fosterage, as seen in Honiara, respond to economic and social transformations.

7 Melanesian societies are societies where children are being fostered out to kin. In Solomon Islands, the practice of having a house girl, and the ideology of the family that sustains it, builds on a fosterage tradition that allowed members of families to claim or foster out children to other households within the extended family, for some time or permanently. However, it is important to note that even in the case of permanent fosterage, full adoption with a change of identity is rare in some areas such as Kwaio on Malaita (Keesing 1970) and very common in others such as Choiseul (Scheffler 1970) and Bellona, a Polynesian outlier (Monberg 1970). Fosterage, we shall recall, does not 'imply a full transfer of the child's jural rights' (Donner 1987: 48). In Solomon Islands, fosterage is referred to as 'feeding' the child and people make a distinction between 
'feeding' a child and 'owning' a child. Foster parents are expected to treat their birth children and their foster children equally well. It is considered a sign of generosity to take a foster child. Foster children have some obligation of care for their foster parents. Reasons leading to fosterage vary cross culturally. Keesing (1970) who analyzes Kwaio fosterage (lagooniwelaga - literally 'feeding') in case of parental death, argues that fostering a child when both parents are alive, or living together, is rare (p.1005). He explains that who has the right to a foster child is linked to lineage and marriage rights: fostering takes place within lineages or clans. In his study of social structure on Choiseul, Scheffler (1965) indicates that both "adoption and fosterage are very common: approximately 41 per cent of the adult married males in my census of 1959-60 had some history of adoption or fosterage" (p. 101). Unfortunately, Scheffler's figures do not distinguish between adopted or fostered children, but he writes that adoption concerns only orphaned children. Donner (1987) explains that on Sikaïana fosterage (haanai- literally 'feeding') takes place to ensure companionship for elderly people and that it is quite common. It reinforces 'bilateral kinship which is the basis for sharing, support and aid for everyone' (57). His 1982 census shows that at 43 per cent, the fosterage rate was quite significant (1987: 47). All fosterage takes place within the descent unit. In all the cases mentioned above, fosterage serves various purposes: it protects orphaned children; it provides company and care; it supplies labor to the foster family; it offers respite for families with many children. Fosterage is not special to Solomon Islands. It is well documented for other parts of the Pacific as well as evidenced, for instance, in the work of Jeudy-Ballini 1998 for New Britain; Young-Leslie 2001; Leblic 2004 for New Caledonia; Modell 1995 for Hawaii).

8 The case of the house girls I am describing here is different from the rural types of Solomon Islands fosterage described above in that it is always only temporary, on an agreed upon term between rural parents and urban kin and thus implies delocalization away from the village to the towns, and its main purpose is to provide labor for the urban kin. In that sense, this fostering also builds on a tradition that has existed, and still exists, in rural areas of getting domestic or garden help from young collateral family members. But it differs significantly from that model of domestic help in that financial compensation is involved.

For my purpose here two things are important: First, as Keesing (1970), Jeudi-Ballini (1992), Strathern (1990), and Leblic (2004) have shown among others, central to this practice is the idea of belonging. Who does the child belong to? Who has the right to claim it? etc. Second, it is possible to think of multiple parental figures, something local kinship terminology reveals. Two stock phrases often heard in Honiara in reference to young girls from the extended family are also used to refer to house girls. They reveal the emphasis on the family links: 'Gele blong mi' and 'mi fidim hem'. Gele blong mi, that can be translated as 'she is my daughter' (niece/grand-daugher/grand-niece), clearly refers to kinship ties. 'Mi fidim hem' is the phrase used to speak about adopted or fostered children and found also in local vernacular languages. In Solomon Islands, bonds of food equate the bond of kinship, as if when offering food to someone, one gives a piece of oneself. This is well documented throughout Melanesia. These stock phrases directly refer to the parental obligations and responsibilities attributed adult kin members and clearly put the house girl under the care of the speaker.

10 As with other dimensions of Melanesian sociality, much revolves around kinship ties and kinship obligations. Kinship is indeed nurturing, but a case is made here, as has 
been made elsewhere (Medick and Sebean, 1986), that kinship relationships are exerting some form of violence on members of the units. Here the violence is mostly symbolic, but also psychological and structural (I am not discussing sexual abuse or domestic violence, though it is reported) and is linked to the power inequity associated with age and gender, and now class, that permeates kin relations in Honiara. But kinship is also a process. How kinship ties are manipulated and used to legitimize extraction of labor; how they are acted upon or not; how they are enacted or withdrawn, all this speaks to the interests and the emotions that link members of a kin group.

\section{Urban living, kin relations, and social differentiation}

11 Rapid urbanization in Solomon Islands is accompanied by rapid sociocultural changes. It is even truer in Honiara, bulging at its seams, than in any other towns of the country. Recent estimates put its population in the vicinity of 85,000 people (SIG 2012). The town is now about 70 years old and its history has roots in the colonial past (Bennett, 1987) and in land alienation from customary landowners (Foukona, 2015; Maggio, 2017). Over the years, the identity of the town changed from that of a typical colonial town - the seat of colonial administration and the port of export of commodities and entries of manufactured goods - in a vibrant post-independence ${ }^{7}$ town that Solomon Islanders have quickly appropriated, culturally and politically (Jourdan, 1996; Moore, 2015). Clearly, administrative inheritances from the British colonial world, linked to the economic demands of globalization and the development of an urban elite culturally familiar with the Western ways of life, constrain, and are in part constitutive of the variety of choices and options that are available to migrants and urbanites in their quest for a cultural world of their own (Jourdan, 1996).

Honiarans are living in a world that is fast changing and where alterity is exacerbated by the coexistence of people from all the ethno-linguistic groups of the country (64 in all). In the course of everyday life, individuals and groups are redefining the cultural expectations and cultural practices they live in and with through a dialogue between individuals and groups that provides both the dynamics that generate broad cultural homogeneity at the level of the group and the heterogeneity of individual practice (Philibert et Jourdan, 1994). But more importantly, the dialogue makes it possible for shared expectations about urban living to be elaborated into a new cultural urban modus vivendi that rural Solomon Islanders recognize as urban (Jourdan, 1996): increasing individuality; the power of money and education; distance from kinship obligations; negotiation and transformation of customary practices; Pijin as the universal medium of the town and the mother tongue of two generations of urbanites.

But living in Honiara is hard socially, physically and economically. Ethnic alterity is experienced daily and challenges one's sense of identity (see McDougall 2016). Indeed, Berg (2000) has argued successfully that urban life in Honiara consists in great part in managing difference. Linguistic and cultural differences have to be negotiated along with different ideologies that govern urban sociality (Jourdan and Angeli, 2014). In addition, urban land is scarce. "Many lower and middle-class inhabitants of Honiara struggle to get access to urban land through formal market and regulatory orders", Foukona explains (2015: 508). This leads to the development of large squatter settlements, as they are called locally, lacking all basic infrastructures (Maggio, 2014). 
Finally, with a stagnant job market, employment is difficult to get, particularly for the young people who represent $56 \%$ of the population of Honiara (SIG 2009). In a town where as people put it 'mifala kaekae long selen' (we eat with money), more and more urbanites depend on the generosity of their kin, churches, and friends, for subsistence. Others have to resort to informal economic activities in order to get the small amount of money that is often needed to feed their family or pay school fees. The town is socially fragile, and so is the livelihood of most of its residents.

In their efforts to be urbanites, Honiarans still have to contend with what some of them refer to as 'the weight of kastom', the locally named reference to general cultural rules of respect, obligations, mutual exchange and social propriety that govern much of the cultural understanding of Solomon Islanders. Urban individuality is at odds with an ideology that favors collective obligations towards kin. As we will see further down in this article, this state of affairs requires that urbanites navigate, with more or less comfort, systems of meaning and behavior that are very different. While some Honiarans have settled roots in town through work, neighborhood and families of procreation and have no ambiguity about their place and life in town, others are more circumspect. 'Hom', the rural place of origin of one's family, doubled with ethnicity, remains for many the primary point of reference for identity. For some, and particularly first and second generation urbanites, as I explained in Jourdan 1996, hom' is the quasi mythical place where one could possibly return if need be, or when one retires. For others, the only 'hom' they know is Honiara, the place they have made their own and where they have lived for three generations: their emplacement in town is geographical, but it is also cultural (Jourdan and Angeli, 2014).

The Honiara house girls analyzed here play an important mediating role between these two forms of sociality: as kin, they embody the ideologies of mutual obligations and exchange. As employee they participate in the establishment and reinforcement of ways of being and acting that are removed from the ideology of reciprocity. This is particularly true of the middle-class, defined here in Weberian terms (see also (Gooberman-Hill, 1999), and which encompasses people as socially and economically diverse as civil servants, small businessmen, teachers and nurses, medical doctors and lawyers. This middle-class has adopted practices of consumption and distinction that set them apart from the working class. Having a house girl is one of them. Beyond the work she does, the presence of a haosgel signals that a household has the means to feed, lodge, and sometimes pay, an additional person on a regular basis. This is not negligible in a town where every thing costs money, houses are small and over crowded, and where food has to be purchased. It also indicates that the family has a need for such help, and that the lady of the house has moved to more important things than having to perform domestic chores. My observations show that house girls are often found, as can be expected, in dual-income families with young children who also have the means to partake of consumer goods such as cars (SIG 2009). The house girl is part of a package of distinction that sets middle-class families apart from their neighbors.

\section{Who are the haosgel in this study?}

16 Typically, the haosgel is a young unmarried Solomon Islands girl with no marketable skills, who will employ herself as live-in domestic worker against wages or compensation in kind, and always against room and board. 

age is 19. One had been in town for only two months at the time of the study; others had been there for six years; the mean time spent in town was 17 months. All were single, a social status conveyed in Pijin, the local variety of Melanesian pidgin, by the word ianggel. Two of the youngest girls went to school. agreements between adults. Some girls were sent from the village by their family and had little say in this decision: the arrangement was made directly between her parents and her urban family. When I asked them how they ended up in Honiara, some girls in my sample simply said:

"Dadi blong mi talem mi for kam" (my father told me to go)

This is usually in response to a request by urban kin for domestic help. Sabina arrived in town in January 1997 because her paternal uncle asked her father to send her. This is how she reports the event:

“Ankol blong mi talem: 'Mi laekem gel blong iu for kam hoasgel for me'. Dadi hem se: 'Oke, you go wetem hem fo waka fo hem, haosgel fo hem'. Den mi kam." (Sabina, 1997) (My uncle said: I want your daughter to be my house girl. My father said: Okay, you go with him and work for him, be his house girl. So I came)

Photo 1. - Little girls washing dishes, Honiara, March 2008

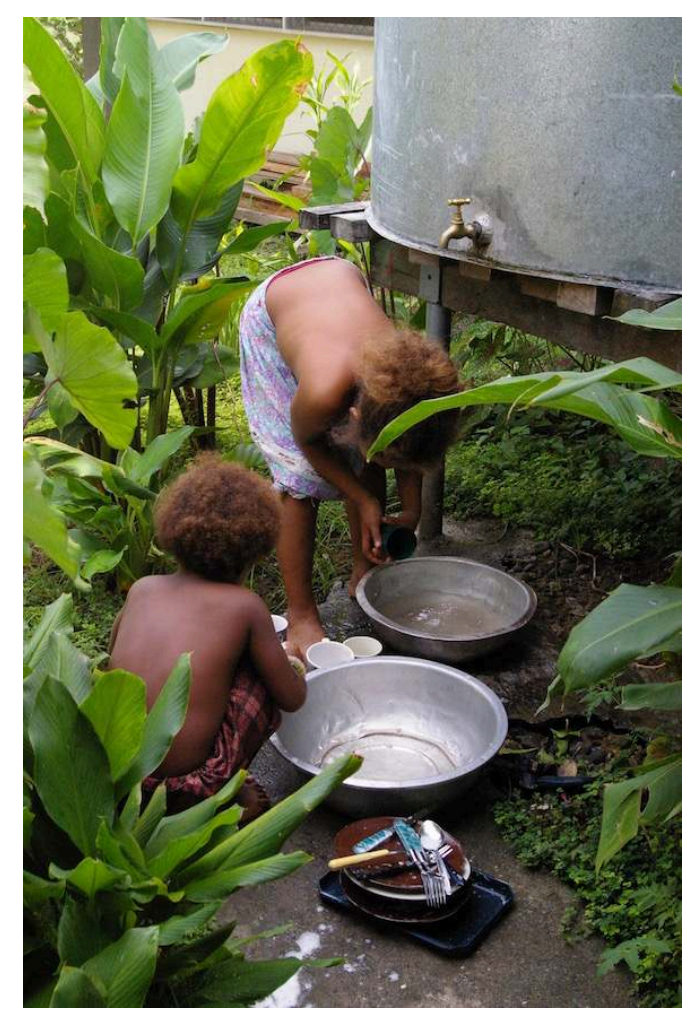

(๑ CHRISTINE JOURDAN)

The logic behind this request is of the same order: pre-existing ties or obligations make it possible. In this particular case, Sabina's father is the younger brother: out of rispek (respect), one of the corner stones of Solomon Islands sociality, he could not refuse the request of his elder brother. Girls also said:

“Ankol blong mi kolem mi kam." (My uncle asked me to come) 


$$
\text { and selfish on the parts of parents to refuse a request from kin to take foster children }
$$
(see also Donner, 1987: 47).

central to the construction of Melanesian sociality despite the geographical and social
distance that separates villagers from urbanites. Though some of the urbanites may have lived in town for at least two generations (almost as long as the life of the town itself) as some of my long-term research participants have, many have kept alive their link to their rural kin. Many navigate carefully and with skill the complex world of obligations to kin and independence from them. Many of the urbanites I know try to mobilize this link to their advantage.

In four cases, it is the young girls themselves who have asked their parents to let them come to town, and to ask on their behalf an urban relative to take them as a haosgel. They were between the age of 17 and 21 and had left school. Lured as they were by the "lights of the town," the girls were eager to come to Honiara and experience it all. From their home in the village, they have constructed a vision of what being a haosgel entails; it includes freedom from parents (they tend to forget that they will be under the watch of their urban hosts), independence for kastom, wokabaot (walking around) in town and leisure time. This quasi-romantic vision of an exciting life fully lived is to some of them a distinct improvement over the life of hard work and general boredom that they associate with their lot in the village. The bonds of kinship will make this experience possible. Some girls spoke of the trip to town as if a rite of passage between childhood and youth, and for some into womanhood, akin to the almost mandatory trip to plantations, to town, to college, that young Solomon Islands men are often expected to take before they marry. But it is also a "process of becoming social» as Alison James puts it (1995: 45) in other social worlds: that of the youth, and that of the urban. When they go home after two years in town, and provided that nothing in their behavior there has contributed to soiling their reputation, the girls are surrounded by an aura of sophistication. Usually, it does not take long before they find a suitor and get married. In the provinces where bridewealth is still paid, their sophistication will fetch a more important price.

It is understood that in offering the service of their daughters to well-established urban folk, her parents confirm pre-existing bonds of exchange and obligation that tie members of an extended family. The girl's labor is a token of this bond: it opens the road for further exchange and obligation. Whether she is apt or able to carry out the work expected from her is clearly taken into account: thus it is preferable to send/ obtain a girl who has had some schooling and has been introduced to the ideology of domesticity taught by schools and churches. Rules of kinship obligation and exchange, therefore, conflate with new gender roles and principles of domesticity imposed by Christian missions and globalization (see Jolly and McIntyre, 1989).

The girls' labor can also be construed as a gift, or a conduit that leads to the procurement of goods, or as an investment. One cannot overlook the return expected from such a gift. For the rural family, the most coveted return of this "gift" will be the possibility of having access to cash (the daughter's wages), to the consumer goods she may bring back, and to lodgings in Honiara when a sojourn in town is planned. They almost always answer positively a request coming from an urban relative. But, invariably, the urban folk are wealthier than the parents of the girls, and endowed with 
the aura of quasi-cosmopolitan sophistication that is often attributed to well establish urbanites in Solomon Islands (see Gooberman-Hill, 1999). Here, financial means and locality create social differentiation within families and interact with rispek and the ideology of kastom.

Many of the girls with whom I closely worked are related to the household through the husband. In Honiara, people say that this arrangement is the safest for the wife, as it ensures that no foul play will take place between the haosgel and the husband (see also Gooberman Hill, 1999: 104). Yet, the data I have for the 28 house girls found in the 80 households in my sample show that 12 are related through the husbands and 16 through the wives. For the wife, the downside of having a house girl that belongs to her husband's kin is that little communication takes place between her and the girl, for reasons often linked to rules of avoidance between in-laws (in-laws are classified as taboo). In these situations, the husband mediates much of the interaction that takes place between the two women: the result is that the wife does not quite control the house girl. In some cases, women explained that they think the haosgel may be spying on them for the benefit of her in-laws and her husband. This may explain that some women prefer to take a girl from their own kin group as haosgel, and sometimes their own sister or cousin. At times, they may expressly ask for a particular girl whom they know as being hard-working, malleable and homely. As Kraemer (2003: 115) remarks with reference to Rollins (1985: 231), the house girl as employee is selected for her personal characteristics and not simply for the labor she can do. Whether they are part of the husband's or wife's kin group, these girls are usually the daughter of a cousin, male or female, or the daughter of a sibling. Women who do not have any family in town seek companionship from their own sister (6 cases out of 28), their female cousin (4 cases) or their niece ( 5 cases) and invite them to be their haosgel. Some women prefer to have a haosgel who is very young so that they can boss her around or simply control her better. These young girls are usually sent to school in town and come home at the end of the school day to do their domestic chores. The host family pays the school fees as a compensation for the work they do in the house.

As part of an urban household, house girls are busy: leisure time is rare with all the tasks that need doing. Some girls complain that they have to work even if they are sick. Their responsibilities often involve being a maid, a gardener, a baby sitter, a guard for the house, and a companion for the wife. At times, they have to fit all these chores around their days at school. Some haosgel enjoy their experience. Yet, after a few months, when homesickness sets in, they think back of home with nostalgia and tend to romanticize the life and work conditions they knew at home. Forgetting how hard women work in rural areas, ${ }^{8}$ the girls sometimes have a tendency to see the village as a safe haven away from the difficulties of town life, something that Jolly and Macintyre (1989: 1) have commented upon with regard to other parts of the Pacific. The following vignette illustrates how busy house girls can be in some households.

\section{Engaging the social scene}

Most haosgel complained of being isolated in the house and not seeing many people. Three factors act to strengthen the social isolation they seem to resent. First, the social make up of Honiara middle class and elite households is often that of a double income family: except for the young children, the house girl finds herself alone all day. Family 
members or wantoks who are visiting do provide companionship, though they also cause additional work, their presence brings solace, and a chance to empty one's heart, to get direct news from the village, and to renew one's kin ties with those left behind. By contrast, in households where the wife is not working, the house girl is supervised all day. Second, and as we saw in the vignette above, a house girl is always busy: her responsibilities within the household are so numerous that it would be difficult for her to find the time to engage in sustained social exchange outside of the immediate household during the day. Finally, parents are concerned that their young house girl daughter may fall victim to the break down of kastom and morality that they associate with urban living. Indeed the practice of fosterage, albeit temporary fosterage, requires that the family who takes the girl in will be responsible for her well being and will look after her well. Keesing (1970) explains that people who mistreat foster children will see them removed from their care. Some girls have been warned about the potential dangers that await a young girl in town and have been painted a picture of the town that is likely to deter them from wandering far from the house. Tina's story reveals the fear that some young girls harbor vis à vis the town:

Tina. "Mi no save wokabaot seleva. Hem stopem mi for go alobaot. Mi les fo go olobaot. Mi fraet" [I do not wander around alone. They are preventing me from going around. I do not want to. I am afraid...]

Christine : "Fraetem wanem?" [Afraid of what?]

Tina: "Fraetem man. Otta save hoholem otta man long road. Kilim man long rod. Bis ples long Mbokona, otta save drink bia insaet bus long dea. So mifala save fraet fo go daon seleva. Mi save ste long hoa. Wantaem, mi go wetem anti blong mi. Mi se: 'Oh! mi fraetem trak, fraetem pipol. Nogud eniwan lukim iumi long rot, otta kilim iumi nomoa. So mi no save wowokaboat. Ste long hao nomoa" [Afraid of men. They mug people in the street. They beat up people in the street. In places like Mbokona [an inner suburb of Honiara] they drink in the wooded areas. So I am afraid of going down alone. I am staying at the house. One day, I went to town with my aunt, and I told her: 'Oh! I am afraid of the cars, afraid of people. Let's hope that no one will see us in the street, they might beat us up'. As a result, I am not wandering around. I am staying in the house.] (Tina, 1998: f) 


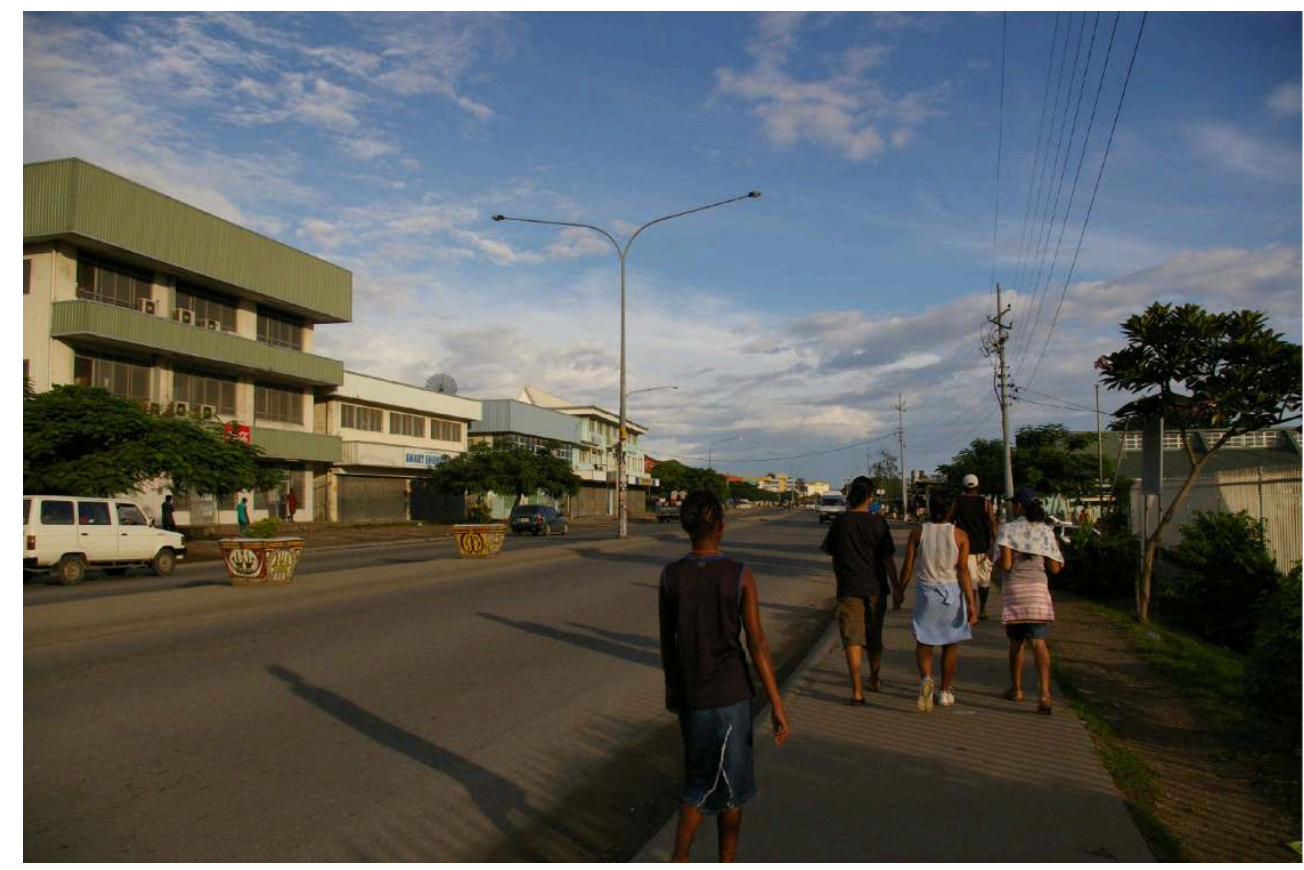

(C CHRISTINE JOURDAN)

Tina's testimony is interesting in its ambiguity. She starts off as if to say that someone is preventing her from going out, a statement consistent with my observations and other testimonies received from other house girls. But it is true that she is also genuinely afraid of being alone in a town where, except for some wantoks she knows, everyone is a stranger, and which has been depicted to her as a place where kastom is gone and morality is loose. Parents insist that their daughter be sheltered from potential dangers, and the urban kin take their responsibility seriously: the last thing they need is a house girl who gets agitated or moody because she has run into trouble or would cause trouble by being seduced or raped and get pregnant, or run away.

The result is that freedom of movement is often antinomic with being a house girl. When she moved to town, a girl practically renounces whatever freedom of movement she had back home, and surrenders her autonomy to the control of her urban kin. In most households, girls' movements, even going to school, are monitored closely and many are not allowed to go to town to market on their own, or to run errands away from the house, though they may be sent to neighborhing households to borrow flour or sugar.

31 Going to church on Saturdays or Sundays provides the social highlight of the week. The young girls are keen on going, and they see being prevented to go on account of household chores as a cruel punishment. In some religious congregations such as the Seventh Day Adventist or Kingdom Harvest congregations, going to church on Saturday or Sunday (go sevis) is often an all-day affair that translates into a social event. There, house girls have an opportunity to meet people and to regain their status as a member of the kin group, simply by virtue of being seen with the family. The shift from one social sphere to another makes it possible for the social erasure that came with their role as house girl to be temporary lifted. 

system comes from the house girls of the neighborhood, and sometimes from another house girl of the household. Some silent understanding exists between them that allows them to recognize the sameness of their situation and their common starvation for social encounters. Tina says that she will deliberately forget an item on the shopping list so as to have an excuse to return to the neighborhood store located 200 meters away. Taking Samo, her five-year-old charge, by the hand as a chaperone, she returns to the shop. On the way, she calls out to neighbors sitting in their yards, jokes with them at a distance hoping that they will tell her to come in, stops in the second hand shop located close to the food store, or goes and chat with the women who are preparing the church for the Sunday mass.

, some will manage to encounter young men and develop a relationship with them. The euphemism used in Pijin is that of fren, best translated as boy-friend. It speaks of an amorous relationship, not necessarily a sexual one, but one that has the potential of becoming sexual. Courtship, exchanges of gifts, and time stolen away from regular activities and the public gaze, are all part of frenim. Mi frenim wanfala boe, girls will say. "I have a romantic attachment to a boy", or "I have a boy friend", is what they mean. For a house girl, this is tantamount to danger, and their family will make sure that it does not develop any further, for fear that rules of propriety be broken. Promiscuity between young unmarried people is still very much looked down upon in Solomon Islands, and rules of sexual propriety are strictly enforced. I have seen house girls being packed and sent home the very day her indiscretions were found out.

"House girls are sources of prestige and problems", wrote Gooberman-Hill in 1999 (1999: 107). In April 2015, the neighbor's house girl Celina got pregnant. She was promptly packed away and brought to live with the family of her boyfriend in another part of town. Over a few nights John, her 'uncle-boss', a well off and long time resident of Honiara, negotiated compensation from the boyfriend's family and insisted that the two should get married. As Celina's guardian and only urban kin, he claimed and collected the first installment of bridewealth. It is clear that many issues came to the fore to stir up his anger. He was furious with Celina, he explained, not so much because of the pregnancy itself, though he resented the fact that she had broken kastom, but because she had some how created problems for him linked to Christian morality and propriety (see Stritecky, 2001; Maggio, 2014), and to his own reputation as a responsible and reasonable urban person who is in control of his household. He explained to me that he considered the girl's pregnancy as a breach of contract at a time when the family needed her labor: he had paid for her passage to town; he had treated her well; he had given her some small wages plus room and board and despite all this she had 'betrayed' him, as he said. Why did the girl not keep her side of the bargain? But he also considered Celina's behavior as a challenge to his authority as head of the household. In a way, John's reaction was very reminiscent of the argument presented by Gewertz and Errington (1999) à propos of the reasonability of the PNG middle-class. Here, it crystallized a new way of being social that combined Christian morality with social responsibility and fairness, kinship obligation with work relations. All this was eminently reasonable in John's mind. Now, he had no option but to find someone else to come and help with the domestic chores of his household.

Journal de la Société des Océanistes, 144-145 | 2017 
35 A girl who wants to stay in Honiara will have to comply with the authority of her kin and with the social parameters of her position as house girl, or use subterfuge or dissimilation. But a girl who wants to go back home before the end of the agreed-upon period may facilitate her return by resisting the system: she can sleep in the morning, she can slow down in her tasks, she can be slack in her obligation, she can become inattentive to the children, she can spend a lot of time chatting with neighbors, and more importantly, she can misbehave according to kastom. The latter includes talking back to her kin, disobeying, disrespecting the rules of address to and behavior towards kin, and, most of all, she can start socializing with young men from the neighborhood as in the case of Celina. Finally, she can run away. Some do, and the social cost to them is horrendous, especially if they elope. Laziness, mixing with boys, and elopement are the clear affirmation of gendered and sexual agency, reminiscent of the wayward women described by Holly Wardlow (2006). These behaviors are deliberate actions that challenge the authoritative control of her kin, and of her male kin particularly. Even if the social cost is high.

\section{Status and money}

Whereas the status of fostered girls in rural areas is clearly that of kin who, as part of a household, have to help with domestic chores, in town their status is ambiguous: both kin and employee, they are treated at once as younger siblings who have chores to perform and as employees who have duties to carry out in exchange for wages. Because they are kin, they participate in family activities and are recognized as such by visiting relatives. Because they are employees, they are often given tasks that no one in the household wants to carry out; they are often left behind to look after the house when the owners go on errands or for an outing, under the pretext that someone has to stay behind and look after the house.

The settling of wages, Gooberman-Hill (1999) points out in her analysis of the place of house girls in Honiara households, is a problem. I contend that this is even worse when the haosgel is a close family member. For one, people do not want it to be said that they treat their young kin as employees; yet the bond established by an exchange of money for work clearly locates the relationship within that of labor relations. Robbins and Akin have remarked on the anxiety provoked by money in Melanesian societies and propose that «If Melanesians regularly work to differentiate kinds of exchanges, kinds of relationships, and kinds of objects, then it is not surprising that despite their quick adoption of money they continue to worry about its power to breach the transactional boundaries they have erected » (1999: 8).

The settlement of wages by money, rather than through recompense in kind (in the form of a trousseau, for instance, or other material goods) compounds the difficulty. Akin's discussion of the effect on money in exchange between close kin in Kwaio (Malaita) illuminates the situation I am describing here. Money brings a negative connotation into the exchange, he explains. And though money is sought, it creates a moral distance from the social relationships that are typically established through the exchange of food, services or shell valuables. Yet, Solomon Islanders are keen to obtain cash through employment or business when they can. Coming to town, seen from the rural areas as the place where employment opportunities exist aplenty, is one way to access cash. Salaried employment is what defines the urban in the eyes of many; it is, 
with a shortage of land in some islands, and the need to access better educational and medical opportunities, one of the main causes of urban drift. Urban middle-class families, with their good houses and consumer goods, are often, if not envied, seen as positive examples of the material comfort employment brings. House girls are no different from other job seekers, and though many will be happy to be compensated in kind for their contribution to the household they are now part of, as they would be at home, others insist on being paid wages for activities they considered to be a job rather than a chore. They want to be kin and be well treated, and they are prepared to work hard, but they also want to get paid.

Photo 3. - Women waiting that the sales begin, Honiara, 2016

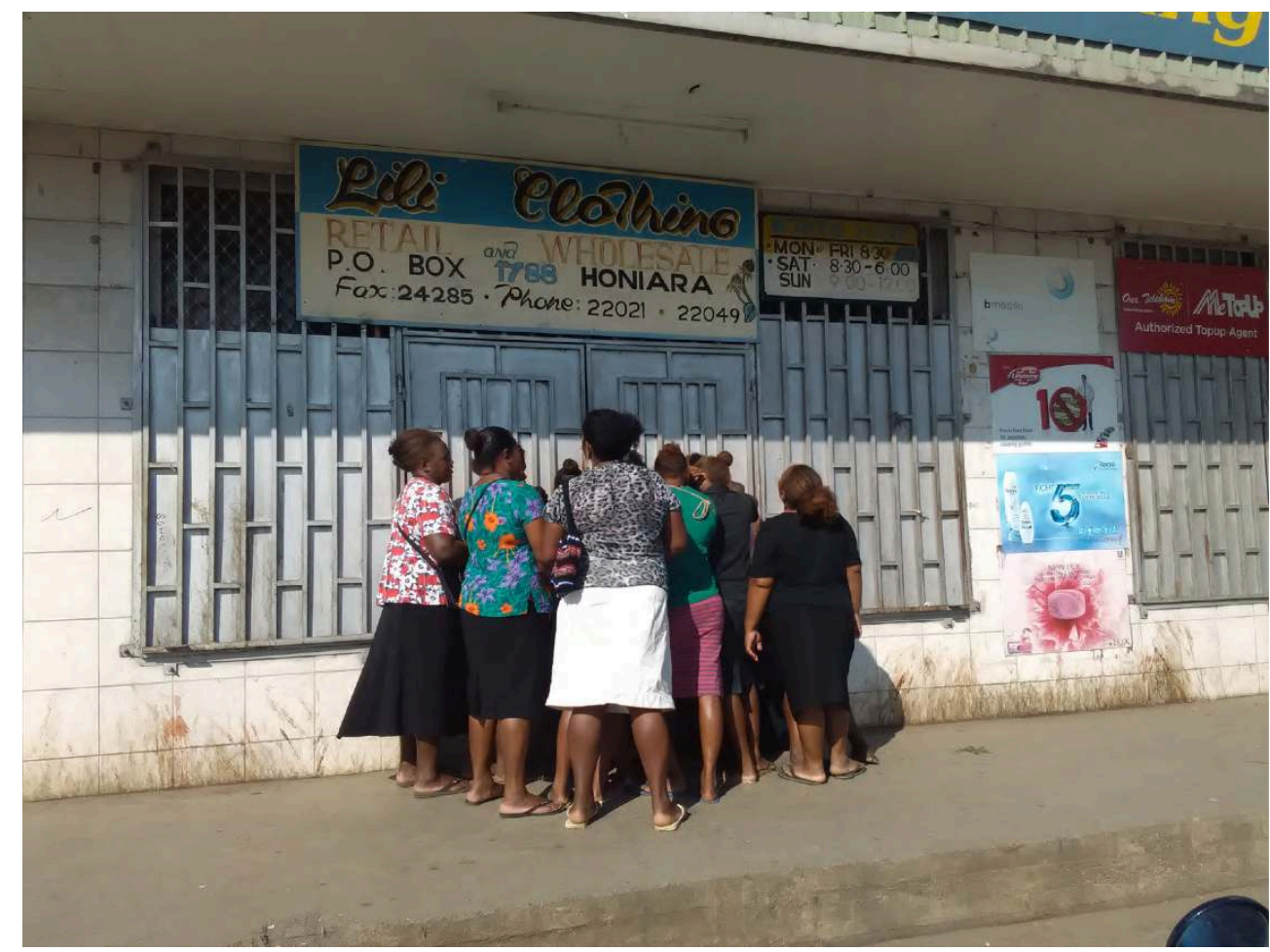

(৫ CHRISTINE JOURDAN) because they directly affect the nature of the kinship relationship. They muddle the relationships between family members by creating an equivocal relationship where a straightforward one existed. The uncle and aunt become bosses whereas they were kin. Wages also challenge this relationship by bringing distinctions between kin that are of an order different from the usual ones. And finally, they bring this relationship outside of the normal sphere of exchange and into that of employer to employee.

Work conditions and financial compensation vary with households. Some women I talked to do not look kindly on families who work their house girls hard and treat them badly, a fact that is corroborated by Gooberman-Hill (1999). If the girls are kin, they should be treated fairly they say; and the work conditions should be clear. Some urban families really want to do right by their young haosgel. They see her as a young charge they are morally responsible for and treat her very well. Some employers send their haosgel to school when they are still of school age. But there also exist cases where the young girl is made to work hard and long: her duties as kin with chores to perform are 
enmeshed with her duties as a servant who has work to do. For instance, against room and board, and a minimum of a few dollars a week for pocket money, some heads of households do not hesitate to make their house girl work long hours, with hardly any free time. Other families are more generous, and give proper salaries to their house girl on a regular basis, all the while integrating them fully into the life of the family. Salaries vary. Lali was paid SDB $\$ 100$ (about US\$20) every fortnight; Tassi was given SDB $\$ 100$ per month (US\$20). Kalua did not receive a salary but was promised a box of clothes, pots and pans and bags of rice to take home. The promise was kept, and she took everything with her when she went home a few months later. Some families pay their house girl in an erratic fashion: Vini was promised SDB $\$ 50$ (US\$10) per month when she arrived in February, and nine months later she had only received $\$ 150$. She felt cheated and exploited, even more so because she kept her side of the bargain and worked hard: she knows that had she stayed home, she could have gotten more money by working on the small copra plantation of her parents.

Bitterness sets in for these girls: rispek is owed to the kinsmen, and they cannot complain (see Lindstrom, this issue). Besides, they usually are too shy to do so, given the difference of generation that separates them from their "employers". Mi fil sem (I am too shy) they say. In some households, people withhold the salary of the house girl during her stay, but send her home with a suitcase full of clothes, household goods, and some money at the end of their time with them. In the old days, this was often the case: the girl would work with the goal and the dream of taking home a suitcase full of goods. Mi tekem bokis blong mi go long hom (I will go home with my suitcase) said Kalua with pride. This is akin to building a trousseau, and many couples I spoke with see providing this as a responsibility towards the girl and her family. Rules of exchange are respected: the girl's parents have done without her work for some time, and in exchange she returns home with some goods they may partake of. Some girls speak of this as mi waka fo bokis blong mi (I work for my suitcase), understood here as 'with a suitcase full of goods.' Second hand clothes, possibly a cheap cell phone, some plastic household goods, some toiletries and medicines, some garden tools, all this constitutes the treasure they bring back home.

The powerlessness experienced by the young girls is linked to the tensions that exist between interests and emotions in family relationships, something A. Strathern has commented upon (1986). In her study of young domestic female helpers in Abidjan Ivory Coast, Melanie Jacquemin (2009) makes a similar analysis: the very young girls who are sent to town to work for their urban kin are caught between a nurturing model of family life that is commented upon positively, and the inequality and extraction of labor they are subjected to. Similarly, in her study of the young 'restavecs' (stay with, from French: reste avec) in Port of Prince, Haiti), Chantal Collard (2004) shows that those who are placed in the households of their family networks, are subjected to the same tensions. In general, their situation is not as good as that of the children of the family in which they live. In some Honiara households, the house girl is considered the poor relative that the urban family is helping by giving her opportunities and a job and is often treated as such. At once insiders and outsiders, their poverty and family ties allow for the girls to be moved from one social sphere (kin) to another (employee).

In the case of the house girls I worked with, good personal relationships that develop between the employee and the employer, the uncle's wife and the niece for instance, are what makes the job acceptable. As is reported in the literature on domestic work 
(Rollins, 1985; Romero, 1992; Kraemer, 2003; Jacquemin 2009), it is the relationship between employer and employee that frames the conditions of work. Good treatment is likely to ensure faithfulness on the part of the house girls who see personal relationships with employers as a vindication of their status as kin. However, good treatment by kin must include fair remuneration in order for house girls to preserve their status and for the family relationships to remain good. Yet, as I explained above, a house girl is almost powerless in the structural relationships that constrain her and her movements.

\section{Kinship and class}

Working as a house girl is a role recognized by the community: in neighborhoods, girls are known as the house girl of so-and-so. Interestingly, that role becomes the defining category of the young girl, and supersedes the kin ties that link her to the household she is part of. For instance, the survey I took in early 1998 in Honiara revealed that every time there was a house girl, she was identified by other members of the household as such. No reference to kinship was volunteered about her, unless the interviewee was pressed, whereas each other member was identified with regard to his or her relation to the main couple of the household. After appropriate conversations and explanations, a preliminary exchange would be:

Q. Hu nao stap long haos? (Who lives here?)

A. John

Q. Hu nao ia? (Who is he?)

A. Olo blong mi. (My husband)

Q. Samfala pipol moa? (Who else?)

A. Pita, hem nao brata blong mi, wetem Tela, misis blong hem. (Peter, my brother, and his wife Stella.)

Q. Hu moa? (Who else?)

A. Samo, hem nao fesbon blong mi; den Mika, gele blong mi, den Seda, mek tu boe blong mi. (Samo, my elder child, then Mika, my daughter, then Seda, my second son)

Q. Samfala pipol moa stap? (Some one else lives here?)

A. Lali.

Q. Hu nao ia? (Who is she?)

A. Haosgele blong mifala. (Our house girl.)

Q. Hem long saed long famili blong iu? (Is she related?)

A. Ia, hem bon long kasin sista blong mi. (Yes, she is the daughter of my cousin).

The label "house girl" itself, with its historical and social connotations, clearly sets her in a different social sphere, apart from the other members of her family, and therefore in a different social class, inferior to that of the employer. As we have seen above, it also distinguishes her from other young cousins and siblings who may be housed temporarily in the household she works for; thus the label, every time it is used, contributes to a temporary erasing of the girl from the kinship system.

Though kinship ties provide the structure for membership in descent units, they do not guarantee social inclusion in the all units at all times. Contextuality is the key for social recognition within the kinship system. In Honiara, house girls experience a structure that includes them but keeps them at distance, or more typically excludes them. Their status shifts with the locale and with the occupations and social responsibilities they have in the locale. Whereas they were full members of the kinship unit in the social 
world of the village, and still are, their position as house girls now supersedes their membership in the kinship unit in town. Not that they are now finding themselves at the periphery of it. They do remain part of it. But they find themselves in a flux, being both kin and employee, alternating between statuses. At times, their being kin is given full recognition and takes precedence (family celebrations, going to church) or being introduced as "anti blong mi" (my niece); at other times, being the house girl takes precedence as in "haos gele blong mi" (my house girl). They are both a member and a non-member. The ties of kinship are what brought them to Honiara; but urban kin ties, centered as they are now on the nuclear family, push them to the margins of the family unit. This marginalization ensures that the urban kin can conceive of the girl primarily as domestic help and that she can be bossed around, asked to performs all the chores that no one wants to do, and in some cases, exploited.

This double bind is violence to them, but a form of violence that is even more insidious and compelling in that it is masked by the inescapable nature of kinship, and the allencompassing ideology of family as nurturing (see also Jacquemin, 2009). For the most part, kin relationships in Honiara are not putting young house girls in physical danger or social alienation. Yet, because of kinship obligations and rules of exchange that focus on, and put a premium on, the circulation of young girls and goods as token of exchange and prestation, these young girls are structurally vulnerable. ${ }^{9}$

Clearly, there are moments of joy in the lives of house girls. It would be remiss of me not to report in this paper on the lighter moments that mark the days of the house girls. Visiting wantoks who bring news from home, birthdays and celebrations that distract from the boredom of the work and bring a festive mood to the house, the banter and play of the children, the visits with the neighbors, a good video played on the VCR, some pocket money obtained in advance, an unexpected trip to Chinatown (one of the shopping areas of Honiara), a good bring and buy at the Church, a mango picked up surreptitiously from under a tree and eaten on the sly before the family wakes up, all these constitute moments of mental escape that bring genuine happiness. And, in fairness, most household owners mean well for their house girls. Yet, the testimonies I have collected are overwhelmingly sad and express disillusion. They resonate very well with those gathered by Daniela Kraemer (2003) in Port Vila (Vanuatu).

\section{Conclusion}

I argued in this paper that the house girls are rendered vulnerable by a kinship system that puts much emphasis on exchange and obligation. Culturally, the circulation of girls is glossed in positive terms. In practice, it is transformed in public discourses of moral worth and value that obliterate individuality. The emphasis on obligations allows the middle class kin to extract the labor of the house girl in order to establish themselves socially and financially. In the name of kinship, the urban middle class has access to cheap labor.

I also argued that the young girls see their status as house girls producing a constant recasting of their identity and social role. The symbolic violence to which they are subjected is both structural and processual. It lies in the activation of relationships (elder versus younger sibling), in the breaking of boundaries (kin versus employee), in the lack of social recognition (erasure), in the fear of being sent home with nothing to 
show for their time in town (exploitation). All this takes place within everyday life in a family atmosphere that is usually rather convivial. As Sheper-Hughes and Bourgois, remind us: "Structural violence is generally invisible because it is part of the routine grounds of everyday life and transformed into expressions of moral worth» (2004: 3).

51 I agree, and showed that her being kin makes it possible for the house girl to be exploited so ruthlessly. The moral tenets that buttress kinship relationships (mutual obligations; rispek; kastom) are being diverted towards the betterment of the urban middle class. Kinship ties are being highjacked to the profit of class interests.

Medick and Sabbean (1986) have remarked that the anthropologist cannot make abstraction of the interests that bind family members. The situations I describe here illustrate clearly that in the larger world of social relationships, kin are both family and partners in production, exchange or inheritance. This duality is characteristic of the bonds that link the house girl to her urban household and open the door for conflicts to emerge at times of transition. Rights and obligations confront each other, and with them attendant interests and emotions. On the one hand, we find the rights of the young girl to receive wages and to be recognized socially, and her obligations as an employee and as a member of a kin-based unit. On the other, we find the emotions attached to being taken advantage of, neglected or ignored, or recognized and rewarded.

Finally, I argued that if having a haosgel is linked to wider changes in domesticity in the contemporary Pacific, such as the greater importance of the nuclear family as the model for domesticity ${ }^{10}$ (Jolly and MacIntyre, 1989), it is also linked to the development of new forms of social relationships within which individuality is given greater recognition, particularly in urban centers. In other contexts, Carsten (2000) has argued that the links between kinship and other forms of relationality are fluid. Here, the girl is an employee; but she is also kin. And vice-versa: She is kin, but she is an employee. Either status comes to the fore of the relationship that ties her to her employee/kin, depending on contexts. In Honiara, paid domestic labor (along with participation in the informal economy, such as selling betel nuts or fresh vegetables by the side roads or selling prepared cooked foods at the market), is one of the main sources of employment for many women, in expatriate or non-expatriate households (sIG Household survey, 2009). It offers opportunities for many urban women to earn some money towards family expenses, usually, food and school fees for children (see also Jourdan, 1987; Pollard, 2000; Knot, 2009). Yet, just as importantly, wages challenge the idea of female domestic labor in Solomon Islands, and what it consists in: It is now a job that one can be paid to do. And given the number of house girls in urban households, domestic work plays an important economic role in the development of the town, and in the reproduction of the middle-class, something Jacquemin (2012) and Collard (2004) have also remarked in their respective studies of fosterage in Abidjan and Port-au-Prince. Wages give domestic labor an economic value that it did not have, even if the employees, as in the case I report on here, are kin.

The blurring of categories between kin and employee hides the extraction of labor that is part of this practice of urban fosterage. It also signals how the context of wage labor changes social relationships. New structures of inequality (here social class) and roles (employee/employer) linked to wage labor develop, in addition to those based on kinship and gender that were already there, and contribute to increase the social differences that exist between the rural and urban areas in Solomon Islands. 


\section{BIBLIOGRAPHY}

AKIN David, 1999. Cash and Shell Money in Kwaio, in D. Akin and J. Robbins (eds), Money and Modernity: state and local currencies in Melanesia, Pittsburgh, University of Pittsburgh Press, ASAO monograph 17, pp. 103-139.

ALBER Erdmute, 2003 (December). Denying biological parenthood: fosterage in Northern Benin, Ethnos 68 (4), pp. 487-506.

BENNETT Judith, 1987. Wealth of the Solomons: a history of Pacific archipelago, 1800-1978, Honolulu, University of Hawai'i Press.

BERG Cato, 2000. Kinship, exchange and urban boundaries in Honiara, Solomon Islands, Unpublished thesis cand. Polit. Bergen, University of Bergen.

BOURGOIS Philippe et Nancy SHEPER-HUGHES, 2004. Introduction: Making Sense of Violence, in N. Sheper-Hughes and P. Bourgois (eds), Violence in War and Peace. An Anthology, Malden, Oxford, Carlton, Blackwell Publishing, pp. 1-31.

CARSTEN Janet (ed.), 2000. Cultures of relatedness: New approaches to the study of kinship, Cambridge, Cambridge University Press.

COLLARD Chantal, 2004. La politique du fosterage et l'adoption internationale en Haïti, in I. Leblic (éd.), De l'adoption. Des pratiques de filiations différentes, Clermont-Ferrand, Presses universitaires Blaise Pascal, pp. 239-287.

DONNER William, 1987. Compassion, kinship and fosterage: contexts for the care of the childless elderly in a Polynesian community, Journal of cross cultural gerontology 2 (1), pp. 43-59.

FEINBERG Richard, 1996. Outer Islanders and Urban Resettlement in Solomon Islands: The Case of Anutans on Guadalcanal, Journal de la Société des Océanistes 103 (2), pp. 207-217.

FOUKONA Joseph, 2015. Urban land in Honiara: Strategies and Rights to the City, The Journal of Pacific History 50 (4), pp. 504-518

GEWERTZ Deborah et Frederick ERRINGTON, 1999. Emerging class in Papua New Guinea: The telling of difference, Cambridge, Cambridge University Press.

GOOBERMAN-HILL Rachael, 1999. The constraints of 'feeling free': becoming middle-class in Honiara, Solomon Islands, Unpublished $\mathrm{PhD}$ thesis, Edinburgh, The university of Edinburgh.

GOODY Esther, 1982. Parenthood and social reproduction, Cambridge, Cambridge University Press.

JACQUEMIN Mélanie, 2012. Petites bonnes d'Abidjan : sociologie des filles en service domestique, Paris, L'Harmattan.

James Allison, 1995.Talking of Children and Youth. Language, Socialization and Culture, in Vered Amit-Talaï and Helena Wulff (eds), Youth Cultures: A Cross-Cultural Perspectives, London, Routledge, pp. 43-62.

Jeudy-Ballini Monique, 1998. Naître par le sang, renaître par la nourriture : un aspect de l'adoption en Océanie, in A. Fine (éd.), Adoptions : Ethnologie des parentés choisies, Paris, Maison des Sciences de l'Homme, pp. 19-44. 
Jolly Margaret et Martha MACINTYRE, 1989. Introduction, in M. Jolly and M. Macintyre (eds), Family and gender in the Pacific: domestic contradictions and the colonial impact, Cambridge, Cambridge University Press, pp. 1-18.

Jourdan Christine, 1987. Être mélanésienne et vivre en ville, Seminar paper presented at ORSTOMParis, Manuscript.

,- 1996 . Where have all the cultures gone: urbanization and creolization in Solomon Islands, in J. Friedman and J. Carrier (eds), Melanesian Modernities, Lund, Lund University Press, pp. 34-52.

-, 1998. Les hommes non-lieu, in D. Guillaud, M. Seysset et A. Walter (éds), Le voyage inachevé. Textes en l'honneur de Joël Bonnemaison, Paris, ORSTOM/CNRS, pp. 423-430.

Jourdan Christine et Johanne ANGELI, 2014. Pijin and shifting language ideologies in Solomon Islands, Language in Society 43 (3), pp. 265-285.

Keesing Roger, 1970. Kwaio fosterage, American Anthropologist 72 (5), pp. 991-1019.

КNOT Michaela, 2009. Fasin laef: Urban women migrant experiences in Honiara, Solomon Islands, M.A. thesis, Concordia University, Department of Sociology and Anthropology.

KRAEMER Daniela, 2003. In the house but not at home: House girls in Vanuatu, Master of Arts in Social Anthropology thesis, York University, Toronto, Canada.

KWAI'OLOA Michael et Ben BURT, 1997. Living Tradition: A Changing Life in the Solomon Islands, London, British Museum Press.

LALLEMAND Suzanne, 1988. Adoption, fosterage et alliance, Anthropologie et sociétés 12 (2), pp. 25-40. LEBLIC Isabelle, 2004a. Présentation : parenté et adoption, in I. Leblic (éd.), De l'adoption. Des pratiques de filiations différentes, Clermont-Ferrand, Presses universitaires Blaise Pascal, pp. 11-23.

- (éd.), 2004b. De l'adoption. Des pratiques de filiations différentes, Clermont-Ferrand, Presses universitaires Blaise Pascal.

-, 2014. From French Polynesia to France: The Legacy of fa'a'amu Traditional Adoption in 'international' adoption, Anthropologica 56 (2), pp. 449-462.

MAGGIO Rodolfo, 2014. Honiara is hard: The Domestic Moral Economy of the Kwara'ae people of Gilbert Camp, Solomon Islands, PhD Thesis, The University of Manchester.

MAGGIO Rodolfo, 2016. "My wife converted me": Gendered values and gendered conversion in Pentecostal households in Honiara, Solomon Islands, The Australian Journal of Anthropology 27 (2), pp. 168-184.

MACDOUGALL Debra, 2016. Engaging with strangers. Love and violence in the rural Solomon Islands, New York and Oxford, Berghann books.

MEDICK Hans et David WARREN SABEAN, 1986. Family and the economy of emotion, in H. Medick and D. Warren Sabean (eds), Interest and emotion: essays on the study of family and kinship, Cambridge and Paris, Cambridge University Press and Éditions de la Maison des sciences de l'homme, pp. 9-27. MITCHELL Jean, 2011. 'Operation restore public hope': Youth and the magic of modernity in Vanuatu, Oceania 81 (1), pp. 36-50.

MODELL Judith, 1995. Nowadays everyone is hanai. Child exchange in the construction of Hawaiian Urban Culture, Journal de la Société des Océanistes 100 (1), pp. 201-219 (http://www.persee.fr/doc/ jso_0300-953x_1995_num_100_1_1964). 
MONBERG Torben, 1970. Determinants of Choice in Adoption and Fosterage on Bellona Island, Ethnology 9 (2), pp. 99-136.

MOORE Clive, 2015. Honiara: arrival city and Pacific hybrid living space, Journal of Pacific History 50 (4), pp. 419-436.

PHILIBERT Jean-Marc et Christine JOURDAN, 1994. Urbi et orbi : Construction identitaire et cultures urbaines en Mélanésie, Journal de la Société des Océanistes 99, pp. 159-166 (http://www.persee.fr/ doc/jso_0300-953x_1994_num_99_2_1933).

POLLARD Alice Aruhe'eta, 1998. Solomon Islands, in T. Tongamoa (ed.), Pacific women: Roles and status of women in Pacific Societies, Suva, Institute of Pacific Studies, University of the South Pacific, pp. 40-56.

--, 2000. Givers of wisdom, labourers without gain: Essays on women in Solomon Islands, Suva, Institute of Pacific Studies, University of the South Pacific.

ROBBINS Joel et David AKIN (eds), 1999. Money and Modernity: State and local currencies in Melanesia, Pittsburgh, Pittsburgh University Press, ASAO monograph 17.

RoluINS Judith, 1985. Between Women: Domestics and their Employers, Philadelphia, Temple University Press.

SCHEFFLER Harold, 1965. Choiseul Island Social Structure, Berkeley, University of California Press. SOLOMON ISLANDS GOVERNMENT STATISTICS OFFICE, 2012. Report on 2009 Population and Housing Census: Basic Tables and Census Description," Vols. 1 and 2. Honiara, Solomon Islands Government.

STRATHERN Andrew, 1987. 'A brother is a creative thing': change and conflict in a Melpa family, in H. Medick and D. Warren Sabean (eds), Interest and Emotion: Essays on the study of Family and Kinship, Cambridge and Paris, Cambridge University Press and Maison des sciences de l'homme, pp. 187-209.

STRITECKY Jolene Marie, 2001. Through a Moral Lens: Morality, Violence, and Empathy in Solomon Islands, PhD Thesis, Anthropology, University of Iowa.

UNICEF ET GOVERNMENT OF SOLOMON ISLANDS (SIG), 1993. A situation analysis of women and children in the Solomon Islands, Honiara.

WARD Marion, 1995. Pacific 2010: Women and employment in Solomon Islands, Canberra, Australian National University, coll. Pacific Policy paper.

WARDLOW Holly, 2006. Wayward women: Sexuality and agency in a New Guinea society, Berkeley, University of California Press.

YOUNG-LESLIE Heather, 2001. Fosterage in Oceania, Routledge International Encyclopedia on Women Studies, London, Routledge (https://heatheryoungleslie.fîles.wordpress.com/2010/01/

fosterageoceania-encyclopedia.pdf, accessed online on February 20, 2016).

\section{APPENDIXES}

\section{A day in the life of a haosgel: a composite vignette}

It is 6:00 am and Kati gets up. Barely awake, she shuffles to the kitchen, her eyes still full of sleep, enveloped in her lavalava that she ties tightly around her chest. Breakfast today, like most days 
when food is available, will include white rice and greens cooked on the spidigit as ${ }^{12}$ stove. Should no food be available, she would have to run to the store and buy the light and fluffy white bread to be soaked in Milo ${ }^{13}$ for breakfast as an alternative to rice and greens. By the time her "bosses" get up, the food is cooked, and she is busy soaking the laundry in the outside sinks.

Missy, her aunt, reaches through the kitchen window and says something to her in a low voice that only Kati can hear. I can see that she nods and frowns. Quickly the family is ready to go: the elder children will be sent to school, in freshly ironed uniforms and with clean white socks in their sandals, while the younger ones have started to play in the garden. The adults rush to their car and leave.

Kati continues the laundry. She is now used to washing her aunt's husband's clothes but she did not like doing it at first: She balked at the idea of having to do it, as it offended her sense of propriety and the rules of avoidance that she must respect towards him. As usual, there is a lot of washing to do: the clothes of four children and two adults are her regular lot. But today is the day to wash the sheets, and already the sun is high when Kati has finished her laundry and has put it on the clothesline to dry.

From where I sit, I can see her there, taking her time to hang the sheets and the clothes, and calling out to Vini, 'our' house girl. The two of them start chatting in low voices and I can see Kati's back trembling from the giggles she tries to suppress. At last, she finishes hanging the clothes, and with her hand nonchalantly resting on the clothesline, Kati exchanges a last word with Vini and returns to the house. She shuffles rather than walks back, her gaze cast down, and rearranges her paréo as she makes her way towards the house, the red laundry basin dangling from her right hand.

Back in the kitchen, she embarks on the dishes: these, she does not like to do. There are many, and her only consolation today is that there is a new bottle of dishwashing liquid that I bought yesterday. It is like a treasure to her, and she takes the time to smell its contents before pouring it into the sink. She likes playing with the bubbles, she tells me, and she often blows on them to watch them fly away.

She realizes suddenly that David, the youngest of the children, has disappeared from her sight, and she calls out to him repeatedly. She is now upset, rushes to the door and comes back pulling a screaming and kicking, and full of mud David by the arm. She locks the door and leaves him sulking in a corner, while she embarks on sweeping and tidying the house. The master bedroom, where the younger children also sleep, is taboo to her, and she skirts around it with the broom, entering the next room and tidying up as she proceeds from room to room. David is now busy playing with his sister Lona and has settled down.

Kati starts cooking again: she is expecting her aunt and her husband back for lunch, and she was told to cook a vegetable stew and sweet potatoes for lunch. Shortly, the couple returns to the house and all start to eat, except Kati: the children are given their plastic plate and eat on the floor, watched by their parents. Kati eats a bit later, sitting on the floor to take advantage of the coolness of the linoleum tiles. After a short nap, the couple leaves again, and Kati picks up the plates, does the dishes, tidies up the kitchen, and finally gets some rest when the children, at last, fall asleep for their afternoon nap.

Today, Kati has decided not to nap: she takes advantage of the presence of a visiting wantok ${ }^{14}$ to leave the children in his care. Purposefully, she goes to the garden. Grabbing her machete, and with the left hand behind her back, she bends over, swings her machete in long regular strokes from right to left and cuts the grass. It is very hot, and she is careful to stay in the shade of the 
mango and rain trees. Like a silent form, she skirts around the trees, and progressively arrives towards the hedge that separates the garden from that of the neighbors. She drops her machete.

Nonchalantly, she bends as if to pick up a weed and swiftly disappears through the hedge. Only the red of her $t$-shirt and the yellow of that of Vini's are visible through the leaves. From the house, one hears nothing. But the children wake up and need tending and the visiting wantok now calls out to her. A minute later, Kati is back in the house, giggling and chatting and embarks on washing the children to cool them off after their nap. This is a moment of pleasure for all, as the children are allowed to sit and play in the big yellow plastic basin that is used for their bath. Kati sits down on the veranda with them and watches them while they play. The noise from the road below increases, as the traffic becomes more intense. It is now close to five and Missy and her husband will be back soon. Kati hurries the children along, washes their face with water and soap, a gesture that triggers much grimacing, fussing and screaming, and finally she has the children dried and dressed.

Just as the parents' car arrives, Kati is ready to pick up the laundry from the line. It is important to do so before the humidity of dusk sets in; otherwise the clothes will smell bad. She does not want to be reprimanded for having forgotten. By six o'clock, it is night. The lights of the neighborhood have come on, and once in a while the headlights from neighbors' cars illuminate the night. One hears the clicking noise of cutlery, the chatter of voices coming from the dark of the verandas, the music from the one radio station that echoes from house to house, and the call of mothers to their children:

"Kom insaed from moskito! (Come inside away from the mosquitoes)".

Missy's husband has brought a bonito from the market, and proceeds to clean and cook it. He is the one who prepares the fish whenever there is some. The bloody juices of the fish run into the sink, and the flies that have made it through the beaten up mosquito wire become agitated. Kati prepares more white rice and cooks it on the speedy gas stove. The dinner is ready.

Tonight, Kati eats with the family, but she prefers to sit in a corner by herself eating silently from her blue plastic plate. Missy's husband intimidates her. After dinner, she clears up the table and does the dishes, while the couple play with their children, read stories to them or socialize with their neighbors. David and Lona have fallen asleep on the floor of the main room, and Kati carries them to bed, one by one. Some time passes, and I do not see her return. Discreetly, she has gone to her bed, in the room she shares with the elder children, and has fallen asleep. It is 9:00 pm. Tomorrow will be her birthday, and she will turn 16.

\section{NOTES}

1. In Solomon Island Pijin, the plural of a word is never marked morphologically. Thus in this paper the spelling of the word haosgel will always remain invariable, whether it is used in the singular or in the plural. A word derived from English "house" and "girl", best translated as domestic help.

2. In the early days, and particularly on plantations, the domestic servant (haosboe, derived from "house" and "boy") was most often a young unmarried man (Bennett, 1987).

3. Pollard (2000) and Knot (2009) have shown that being a haosgel is one of five main types of women employment in Honiara. 
4. House girls who hire themselves out for wages in non-kin households are not included in my analysis, even though they represent an interesting category of worker that harks back to the colonial period.

5. The data on which this paper is based were collected in Honiara in 1997 and February 1998 and updated in 2008 and 2015 with a grants from the Social Sciences and Humanities Research Council of Canada. I wish to thank the women who graciously answered my questions and who are represented here by pseudonyms. An earlier version of this article was first presented at the meetings of ASAO in 2008. This version was presented at the weekly seminar of CREDO-EHESS Marseille in 2014 and I thank seminar participants for their comments and questions.

6. In her 2003 article, E. Alber lists some functionalist argument that have been offered for the existence of this practice: to education opportunities; to even the number of children among households; to distribute the burden of parenthood; help strengthen cohesion among kin groups; help minimize the risks of barrenness.

7. Independence was handed down by Britain in 1978.

8. 'Women in Solomon Islands work longer hours than men' (Ward, 1995: 18). On women's work in rural areas of the Solomon Islands see also Pollard (1988) and Unicef (1993).

9. Note that young boys sent to their urban kin are not exposed to the same types of tensions. Though some are expected to help out with business or gardening (see also Kraemer this issue), their condition as kin is always clear.

10. The nuclear family has become the preferred mode of urban household arrangements in middle class families, though in practice, such arrangements are rare. In poorer households, it is not rare to find that the extended family is the preferred mode: Families often cohabit and share the cost of rent and utilities. The arrangement most often links siblings and their families, or parents and children and their spouses.

11. Pidgin word of melanesian origin meaning 'pareo'.

12. Pidgin word meaning 'gas stove'. Brand name now used as a generic term.

13. Brand name for a chocolate powder used to make instant drink.

14. Someone who typically belongs to the same ethnolinguistic group. In this context, we are referring most specifically to members of one's kin group though the semantic field has expanded over the years to include, friends, colleagues, fellow members of sports team and other people one feels some form of connection with.

\section{ABSTRACTS}

In Honiara, Solomon Islands, middle-class households routinely include young unmarried girls who hail from the villages to work as domestic help (haosgel in Solomon Islands Pijin) for their kin. Using data gathered in Honiara over the last 15 years, and more recently in 2015, the paper explores what is it to be a young haosgel in Honiara today while focusing on a set of issues that are central to the life of these young women: the power and transformation of kinship; the relationship between urban life and domesticity, and the link between agency, gender and resistance. Arguing that the presence of house girls contributes to the establishment of the middle-class, I seek to understand how these young women engage a complex situation in which their urban relatives, usually wealthier than their own parents, act out kinship while playing boss. 
À Honiara, capitale des îles Salomon, les maisonnées de la classe moyenne comportent souvent des jeunes filles qui viennent des zones rurales pour y travailler comme domestique (haosgel en pjin des Salomon). À partir de données recueillies pendant les quinze dernières années et, plus récemment, en 2015, cet article explore ce que c'est qu'être une haosgel à Honiara. Il met l'accent sur des aspects centraux de la vie de ces jeunes femmes : le pouvoir et la transformation des relations de parenté ; le rapport entre la vie urbaine et la domesticité et l'exploitation de leur travail par leur parenté. Soutenant l'idée que la présence des haosgel contribue au développement de la classe moyenne urbaine, j'analyse la façon dont ces jeunes femmes vivent cette situation complexe qui permet à leur famille urbaine, généralement mieux nantie financièrement que leur parents, de jouer sur les liens de parenté tout en agissant comme patrons.

\section{INDEX}

Keywords: kinship, fosterage, young girls, housegirls, social class, urbanization, Solomon Islands Mots-clés: parenté, fosterage, jeunes filles, domestiques, classes sociales, urbanisation, îles Salomon

\section{AUTHOR}

\section{CHRISTINE JOURDAN}

Professor, Department of Sociology and Anthropology, Concordia University, Montréal, Canada Christine.Jourdan@concordia.ca 